\title{
VARIATION PLANT DISTANCE GROWTH RESPONSE RED ALGAE (Eucheuma cottonii) IN WEDIKAN VILLAGE, WEST LUWUK DISTRICK BANGGAI REGENCY
}

\author{
Sri Sukari Agustina ${ }^{1}$ dan Rony Tia $^{2}$ \\ ${ }^{1}$ Staff Pengajar Program Studi Budidaya Perairan Fakultas Perikanan \\ Universitas Muhammadiyah Luwuk Banggai \\ ${ }^{2}$ Alumni Program Studi Budidaya Perairan Fakultas Perikanan \\ Universitas Muhammadiyah Luwuk Banggai
}

\begin{abstract}
$A B S T R A C T$
The purpose of research is to know variation plant distance growth response red algae (Eucheuma cottonii). This research is done in April until June 2005. Randomized Completely Design (RCD) was used for this experiment. The plant distance were arranged in three treatments (treatmean $A=20 \mathrm{~cm}$, treatment $B=30 \mathrm{~cm}$ and treatment $C=40 \mathrm{~cm}$ ). and three replication was use. The data was analyzed by Analysis of variance (Anova). If there is significant effect between treatment, the analysis was continoud by least significant differences $(L S D)$ test treatment. The result of this experiment shows that variation plant distance (treatmen $A$, treatment $B$ and treatment $C$ ) doesn't show effect significant growth rate response red algae (Eucheuma cottonii).
\end{abstract}

\section{KEYWORDS : plant distance, red algae}

\section{PENDAHULUAN}

Indonesia merupakan negara kepulauan yang dua pertiga wilayah negaranya adalah laut dan lautan dengan 13.667 buah pulau besar maupun kecil, serta mempunyai garis pantai terpanjang di dunia, yaitu kurang lebih 80.781,42 km. Kekayaan alam didalamnya pun luar biasa banyaknya, terutama dengan keanekaragaman jenis hewan (fauna), tumbuh-tumbuhan (flora) serta bahan tambang dan mineral ( Hidayat $d k k, 1990$ ).

Potensi laut Indonesia yang sedemikian baiknya kurang dimanfaatkan secara optimal serta tidak diimbangi pula dengan usaha pengembangan lebih lanjut. Sebagian besar petani ikan (nelayan) hanya melakukan kegiatan pemungutan hasil laut saja tanpa adanya usaha - usaha pengembangan, namun demikian ada juga sebagian kecil yang sudah mulai dikembangkan, seperti pembudidayaan beberapa jenis ikan, udang dan rumput laut sendiri. Rumput laut merupakan hasil perikanan yang bukan berupa ikan, tetapi berupa tanaman. Usaha budidaya ini dilakukan mengingat potensi rumput laut sebagai salah satu komoditas ekspor non migas ternyata mempunyai prospek ekonomi yang cukup cerah (Hidayat dkk., 1990 ). Selanjutnya Romimohtarto dan Sri Juwana (2001) menyatakan bahwa tingginya keanekaragaman jenis biota di laut barangkali hanya dapat ditandingi oleh keanekaragaman jenis biota di hutan hijau tropik di darat, tidak kurang dari 833 jenis tumbuhan laut (algae, lamun dan mangrove).

Usaha budidaya rumput laut merupakan usaha yang cukup mudah, murah dan bernilai ekonomis dimana dengan sedikit investasi ditambah semangat keterampilan dan pengetahuan dalam waktu sekitar 45 hari telah dapat memberikan hasil (panen). Keberhasilan mutu usaha budidaya rumput laut ditentukan oleh proses produksi dan faktor lingkungannya seperti : lokasi budidaya, bibit rumput laut, metode budidaya, pemeliharaan, panen dan pasca panen. Salah satu persyaratan dalam metode budidaya rumput 
laut adalah jarak tanam. Jarak tanam pada rumput laut sangat berpengaruh terhadap laju pertumbuhan (Aslan, 1991).

Di daerah Sulawesi Tengah, khususnya Kabupaten Banggai Kepulauan sudah banyak dikembangkan budidaya rumput laut jenis Eucheuma pada tahun 1995, sedangkan untuk wilayah Kabupaten Banggai belum banyak dikembangkan. Di Desa Uwedikan Kecamatan Luwuk Timur Kabupaten Banggai budidaya rumput laut belum mendapat perhatian yang serius dari pembudidaya ikan, namun potensi perairannya cukup baik. Masalah yang dihadapi oleh pembudidaya rumput laut di Desa Uwedikan Kecamatan Luwuk Timur Kabupaten Banggai adalah jarak tanam yang sangat bervariasi sesuai keinginan pembudidaya.

Dari pokok permasalahan ini, penulis melakukan penelitian variasi jarak tanam terhadap pertumbuhan rumput laut (Eucheuma cottonii) di perairan Desa Uwedikan Kecamatan Luwuk Timur Kabupaten Banggai. Sedangkan tujuan daripada penelitian ini adalah untuk mengetahui variasi jarak tanam terhadap pertumbuhan rumput laut dan diharapkan dari hasil penelitian ini sebagai suatu informasi positif bagi pembudidaya rumput laut serta informasi yang bermanfaat untuk penelitian-penelitian selanjutnya.

\section{METODE PENELITIAN}

\section{Tempat dan Waktu Penelitian}

Penelitian ini dilakukan di perairan

Desa Uwedikan Kecamatan Luwuk Timur Kabupaten Banggai selama kurang lebih 2 (dua) bulan, mulai bulan April sampai dengan bulan Juni 2005
Alat :
1. Gergaji potong 1 buah
2. Parang 1 buah
3. Pisau 1 buah
4. Jarum karung 1 buah

5. Refractometer 1 buah

6. Termometer Suhu 1 buah

7. Sechidish 1 buah

8. Timbangan yang menggunakan skala gram 1 buah.

9. $\mathrm{pH}$ lakmus

10. Masker 1 buah

11. Perahu 1 buah

12. Pengukur waktu (jam)

\section{Bahan :}

1. Bibit rumput laut (Eucheuma cotonii) sebanyak 45 rumpun ( $4,5 \mathrm{~kg}$ ).

2. Tali nylon PE $\varnothing 5 \mathrm{~mm} 20 \mathrm{~m}$

3. Tali nylon PE $\varnothing 1 \mathrm{~cm} 40 \mathrm{~m}$

4. Jangkar (sauh) 4 buah.

5. Bambu / kayu siku-siku rakit

6. Tali rapia 4 macam warna secukupnya.

7. Bambu 3 batang, panjang masing-masing $5 \mathrm{~m}$ dan $\varnothing \pm 5 \mathrm{~cm}$.

8. Lilin sedang 2 batang

9. Karung gula 4 lembar

10. Jaring insang (gillnet)

11. Pelampung penyangga 12 buah botol fanta 1,5 liter

12. Pelampung 1 buah dan benang 6 meter

13. Pelampung pengaman 1 buah

\section{Rancangan Penelitian}

Dalam penelitian ini, rancangan yang dipergunakan adalah Rancangan Acak Lengkap (RAL). Sebagai perlakuan adalah jarak tanam rumput laut yang berbeda, yaitu perlakuan A (jarak tanam $20 \mathrm{~cm}$ ), perlakuan B (jarak tanam $30 \mathrm{~cm}$ ) dan perlakuanC (jarak tanam $40 \mathrm{~cm}$ ). Masingmasing perlakuan memiliki 3 (tiga) kali ulangan. Variabel yang diamati adalah pertumbuhan (pertambahan bobot) daripada rumput laut. 


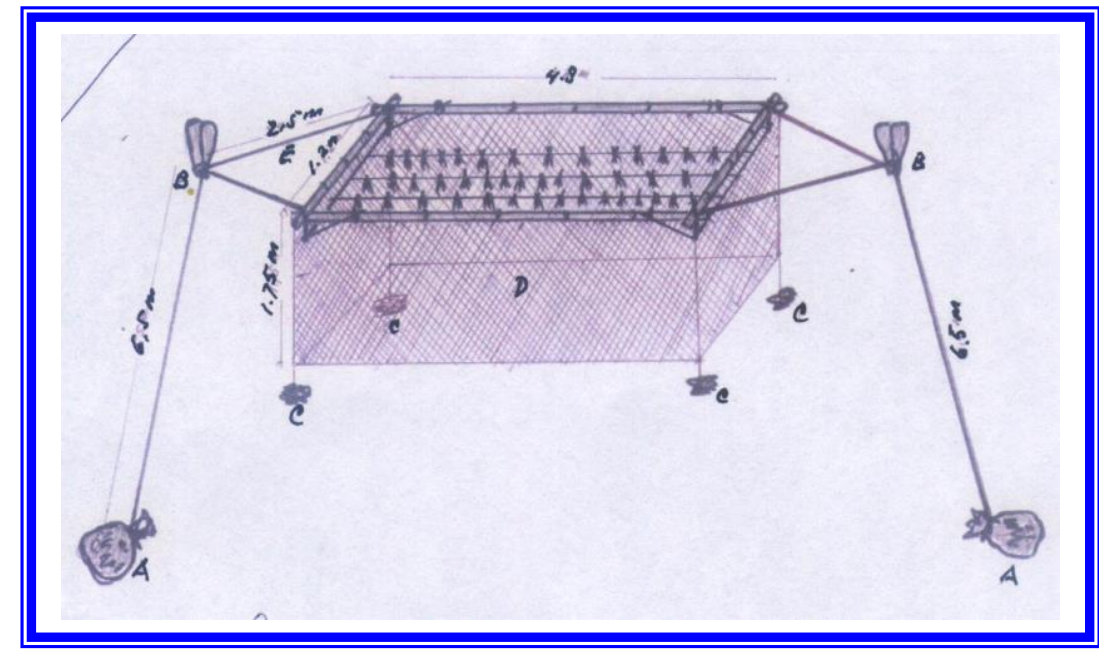

Gambar 1 : Metode rakit yang digunakan dalam penelitian

$\begin{array}{cl}\text { Keterangan: } & \\ \text { A } & : \text { Jangkar/pemberat } \\ \text { B } & \text { : Pelampung penyangga } \\ \text { C } & \text { : Pemberat jaring pengaman } \\ \text { D } & \text { : Jaring pengaman } \\ \text { E } & \text { : Tali penyangga } \\ \text { N } & \text { : Rumput laut }\end{array}$

\section{Prosedur Penelitian}

Prosedur yang ditempuh dalam kegiatan penelitian ini mencakup persiapan percobaan, pelaksanaan percobaan, dan serangkaian pengukuran peubah. Berikut ini diuraikan prosedur dimaksud.

(1) Persiapan percobaan

- Menyiapkan bambu 2 batang yang memiliki panjang masing-masing $5 \mathrm{~m}$ dan 2 batang dengan panjang 1,4 $\mathrm{m}$.

- Jangkar (saus) dari karung gula yang diisi pasir sebagai pemberat sebanyak 2 lembar.

- Tali nylon PE $\varnothing 5 \mathrm{~mm} 30 \mathrm{~m}$

- Tali nylon PE $\varnothing 1 \mathrm{~cm} 40 \mathrm{~m}$

- Kayu untuk pasak 4 potong panjang 35 $\mathrm{cm}$, untuk siku-siku 4 potong panjang 50 $\mathrm{cm}$ dan untuk palang tempat mengikat tali ris 2 potong panjang $1,4 \mathrm{~m}$.

- Tali rapia secukupnya sebanyak 4 warna
- Jaring insang (gill net) dengan panjang 18 $m$ dengan tinggi $1,75 \mathrm{~m}$.

- Bibit rumput laut (Eucheuma cottonii) umur 20 hari dari Teluk Bilalang Desa Uwedikan Kecamatan Luwuk Timur sebanyak 4,5 kg.

(2) Pelaksanaan percobaan

- Pengisian pasir pada karung gula pasir dengan ukuran $2 / 3$ bagian sebanyak 2 buah sekaligus pemasangan pelampung penyangga di lokasi budidaya dengan memperhitungkan rentang tali jangkar yaitu pada air pasang tertinggi dengan kedalaman air laut tempat penelitian $6,5 \mathrm{~m}$.

- Pembuatan rakit dari bambu dengan ukuran $4,8 \times 1,2 \mathrm{~m}^{2}$ sekaligus pemasangan di lokasi budidaya pada tali jangkar pelampung yang sudah tersedia.

- Memotong tali ris sebanyak tiga utas masing-masing $5 \mathrm{~m}$ dari tali rapia 
sebanyak 45 utas dengan masing-masing panjang $35 \mathrm{~cm}$. Memasukkan tali rapia pada sela-sela lilitan tali ris (nylon) dengan menggunakan jarum karung pada tempat yang disesuaikan dengan jarak perlakuan secara acak.

- Menimbang bibit rumput laut untuk masing-masing rumpun seberat 100 gram/rumpun sekaligus diikatkan pada tali rapia yang sudah terpasang pada tali ris sebanyak 45 rumpun. Kegiatan ini dilakukan secepat mungkin, untuk menjaga agar bibit rumput laut tidak mengalami penurunan mutu. Bibit yang sudah diikat pada tali ris segera dibawah dan diikat pada rakit tempat budidaya yaitu pada palang kayu yang letaknya 25 cm di bawah permukaan air laut..

- Pengukuran berat tiap individu dari masing-masing jarak tanam dilakukan 2 (dua) minggu sekali untuk memperoleh data berat.

- Pengamatan kualitas air dilakukan setiap minggu pada jam 06.00, 1300 dan jam 17.00 wita, untuk pengukuran suhu menggunakan termometer air, pengukuran salinitas menggunakan Refraktometer, pengukuran $\mathrm{pH}$ menggunakan $\mathrm{pH}$ kertas, pengukuran kecerahan menggunakan Sechidish dan pengukuran arus menggunakan pelampung.

\section{Pengukuran Peubah}

Perhitungan pertumbuhan menggunakan rumus yang dikemukakan oleh Fortes (1981) sebagai berikut :

$$
\operatorname{GR}(\%)=\frac{W t-W o}{\text { Wo.t }} \times 100
$$

Dimana :

GR : Laju Pertumbuhan

Wt : Berat Akhir

Wo : Berat Awal

t : Waktu

\section{Analisis Data}

Data dianalisis dengan analisis varian. Apabila terdapat pengaruh yang nyata dilanjutkan dengan uji BNT untuk mengetahui perbedaan diantara perlakuan.

\section{HASIL DAN PEMBAHASAN \\ Pertumbuhan}

Sesuai hasil percobaan variasi jarak tanam terhadap pertumbuhan rumput laut (Eucheuma cottonii) di perairan Desa Uwedikan Kecamatan Luwuk Timur Kabupaten Banggai diperoleh data pertumbuhan rumput laut pada Tabel 1.

Tabel 1 : Data pertumbuhan rumput laut (Eucheuma cottonii) selama penelitian.

\begin{tabular}{|c|c|c|c|c|c|c|c|c|}
\hline \multirow{2}{*}{$\begin{array}{c}\text { Perlakuan dan } \\
\text { Ulangan }\end{array}$} & \multirow{2}{*}{ W0 } & \multicolumn{2}{c|}{$\begin{array}{c}\text { Penimbangan } \\
\text { ke-I (14 hari) }\end{array}$} & \multicolumn{2}{c|}{$\begin{array}{c}\text { Penimbangan } \\
\text { ke- II (14 hari) }\end{array}$} & $\begin{array}{c}\text { Penimbangan } \\
\text { ke-III (14 hari) }\end{array}$ & \multirow{2}{*}{ GR } \\
\cline { 2 - 7 } & & W1 & GR1 & W2 & GR2 & W3 & GR3 & \\
\hline A 1 & 100 & 180 & 5,71 & 325 & 5,75 & 400 & 1,64 & 4,37 \\
2 & 100 & 175 & 5,35 & 275 & 4,08 & 450 & 4,54 & 4,66 \\
3 & 100 & 180 & 5,71 & 250 & 2,78 & 300 & 1,43 & 3,31 \\
B 1 & 100 & 180 & 5,71 & 300 & 4,76 & 375 & 1,79 & 4,09 \\
2 & 100 & 195 & 6,78 & 300 & 3,85 & 425 & 2,98 & 4,54 \\
3 & 100 & 170 & 5,00 & 250 & 3,36 & 450 & 5,71 & 4,69 \\
C 1 & 100 & 155 & 3,92 & 250 & 4,38 & 400 & 4,29 & 4,20 \\
2 & 100 & 180 & 5,71 & 300 & 4,76 & 400 & 2,38 & 4,28 \\
3 & 100 & 185 & 6,07 & 300 & 4,44 & 350 & 1,19 & 3,90 \\
\hline
\end{tabular}

Keterangan :

Wo = Berat awal rumput laut (gram)

W1-3 = Berat rumput laut pada waktu penimbangan ke 1-3 (gram)

GR1-3 = Laju pertumbuhan rumput laut pada waktu penimbangan ke 1-3 (\%)

GR = Laju pertumbuhan rumput laut selama penelitian (\%) 
Setelah diadakan perhitungan diperoleh analisis variansi laju pertumbuhan rumput laut (Eucheuma cottonii) pada Tabel 2 berikut :

Tabel 2: Analisis variansi laju pertumbuhan rumput laut (Eucheuma cottonii) selama penelitian

\begin{tabular}{|l|c|c|c|c|c|c|}
\hline \multicolumn{1}{|c|}{$\begin{array}{c}\text { Sumber } \\
\text { Keragaman }\end{array}$} & $\mathrm{db}$ & $\mathrm{JK}$ & $\mathrm{KT}$ & F hitung & \multicolumn{2}{|c|}{ F Tabel } \\
\cline { 1 - 3 } & & & & & $5 \%$ & $1 \%$ \\
\hline Perlakuan & 2 & 0,21 & 0,105 & $0,704^{\text {tn }}$ & 5,14 & 10,92 \\
Galat & 6 & 0,28 & 0,213 & & & \\
\hline Total & 8 & 1,49 & & & & \\
\hline
\end{tabular}

Keterangan : $\mathrm{tn}=$ tidak nyata pada taraf $\alpha<0,05$

Berdasarkan Tabel 2 di atas, menunjukkan bahwa masing-masing perlakuan yang dicobakan, tidak memberikan pengaruh yang nyata terhadap pertumbuhan rumput laut (Eucheuma cottonii). Dengan kata lain, perlakuan variasi jarak tanam $20 \mathrm{~cm}, 30$ $\mathrm{cm}$, dan $40 \mathrm{~cm}$ tidak mempengaruhi pertumbuhan rumput laut ( $\mathrm{F}$ hitung $<\mathrm{F}$ tabel $5 \%$ ). Perlakuan variasi jarak tanam $20 \mathrm{~cm}, 30$ $\mathrm{cm}$, dan $40 \mathrm{~cm}$ tidak mempengaruhi pertumbuhan rumput laut, hal ini disebabkan karena dalam proses pertumbuhan rumput laut (Eucheuma cottonii) di lokasi penelitian dipengaruhi oleh beberapa faktor antara lain :

1. Lokasi budidaya

Lokasi budidaya pada penelitian rumput laut di perairan Desa Uwedikan Kecamatan Luwuk Timur Kabupaten Banggai tidak jauh dari pemukiman/perumahan penduduk $\quad( \pm$ $100 \mathrm{~m}$ dari garis pantai). Hal ini merupakan salah satu penyebab pertumbuhan rumput laut terhambat $( \pm$ 400 gram selama 1,5 bulan). Menurut Winarno (1990) menyatakan bahwa lokasi yang dipilih hendaknya perairan yang bebas polusi, baik polusi limbah domestik maupun limbah dari industri. Selanjutnya Indriani dan Suminarsih (1999), menyatakan bahwa tanaman rumput laut jenis Eucheuma cottonii dapat dipanen setelah mencapai umur $6-8$ minggu setelah tanam dengan berat ikatan sekitar 600 gram. Dinyatakan pula bahwa syaratsyarat pemilihan lokasi budidaya jenis
Eucheuma sebaiknya jauh dari pengaruh daratan.

2. Musim Budidaya

Musim yang berlangsung selama penelitian yaitu musim hujan (bulan April sampai dengan bulan Juni 2005), hal ini sangat mempengaruhi proses pertumbuhan rumput laut. Dimana curah hujan yang tinggi menyebabkan proses fotosintesa pada rumput laut terhambat. Di samping itu pula air laut menjadi keruh, hal ini terlihat terdapatnya lumpur yang menempel pada rumput laut. Terjadinya hujan secara tiba-tiba akan mempengaruhi ekologi perairan di sekitar lokasi penelitian rumput laut tersebut. Hal ini sangat berpengaruh terhadap pertumbuhan rumput laut yang diteliti.

Menurut Winarno (1990), penentuan lokasi budidaya sangat erat hubungannya dengan ekologi perairan, terutama sifat fisika kimianya. Selain memerlukan tempat menempel, rumput laut juga memerlukan sinar matahari untuk dapat melangsungkan fotosintesis. Fotosintesis berlangsung tidak hanya dibantu dengan sinar matahari, tetapi juga zat hara sebagai bahan makanannya Zat hara rumput laut diperoleh dari air sekelilingnya. Penyerapan zat hara dilakukan melalui seluruh bagian tanaman. Sedangkan Hidayat (1990) menyatakan bahwa air yang keruh sering menghambat proses fotosintesis karena menghalangi sinar 
matahari yang masuk kedalam air sampai ke tanaman.

3. Gerakan air

Di lokasi penelitian gerakan air yang ada selama penelitian sangat lambat hal ini terlihat dari data pengukuran kecepatan arus hanya 5-6,5 cm/detik. Gerakan air juga mempengaruhi laju pertumbuhan rumput laut secara tidak langsung. Gerakan air, selain berfungsi untuk mensuplai zat hara juga membantu memudahkan rumput laut menyerap zat hara, membersihkan kotoran yang ada dan melangsungkan pertukaran $\mathrm{CO} 2$ dengan $\mathrm{O} 2$ sehingga kebutuhan tercukupi. Menurut Indriani dan Suminarsih (1999), gerakan air mengalir yang baik untuk pertumbuhan rumput laut antara 20-40 cm/detik. Bila gerakan air lebih cepat dapat terjadi kerusakan tanaman seperti patah, robek atau terlepas dari substratnya. Selain itu penyerapan zat hara akan terhambat karena belum sempat diserap tetapi telah dibawa kembali oleh air dan air laut menjadi keruh.

Berdasarkan data hasil percobaan, Gambar 2 disajikan untuk memperlihatkan laju pertumbuhan rumput laut untuk setiap perlakuan yang dicobakan. Dari gambar ini dapat dilihat bahwa masing-masing perlakuan, menunjukkan perbedaan tidak nyata terhadap laju pertumbuhan rumput laut (Eucheuma cottonii) yang diteliti.

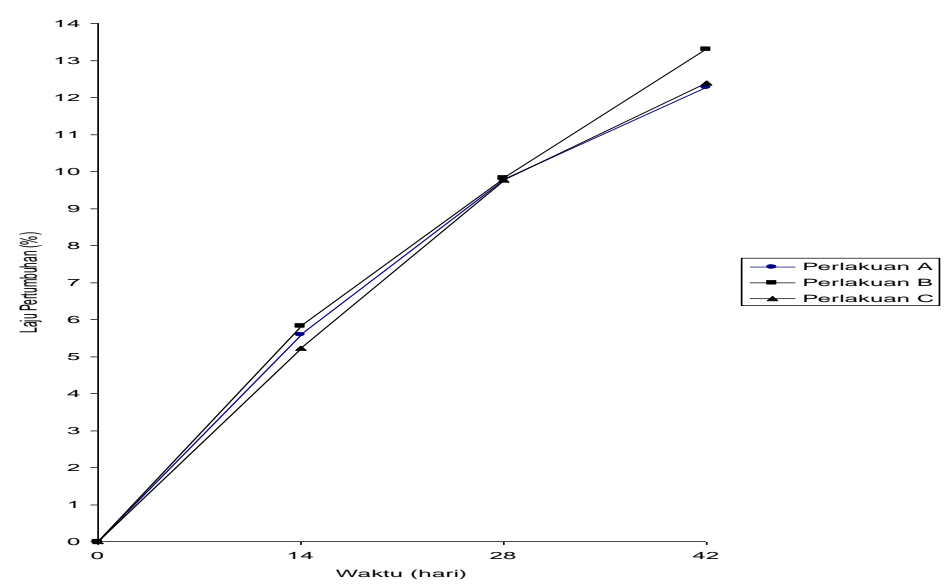

Gambar 2 : Laju pertumbuhan rumput laut (Eucheuma cottonii) selama penelitian

Pada hari pertama sampai hari keduapuluh delapan, laju pertumbuhan rumput laut yang diteliti, nampak cukup stabil, namun menginjak hari berikutnya sampai hari terakhir penelitian, pertumbuhannya mengalami laju yang semakin menurun dibandingkan hari-hari sebelumnya. Penurunan ini terjadi karena rumput laut yang diteliti umurnya mulai menua dan nampaknya telah mencapai pertumbuhan maksimum, dan pada saat itu pula bagian-bagian dari tanaman tersebut banyak yang patah karena semakin rimbun dan bebannya semakin berat. Selain itu, rumput laut yang diteliti mulai terserang penyakit.

Menurut Winarno(1990), dalam usaha budidaya rumput laut sebaiknya dipilih bibit unggul yang mampu memenuhi beberapa persyaratan. Dari segi fisik, alga tersebut harus kuat dan tahan terhadap cuaca buruk terutama terhadap ombak, sehingga dapat dihindarkan terjadinya kerontokan, di samping jenis alga ini haruslah memiliki angka pertumbuhan harian yang cukup baik sehingga produktivitasnya akan tinggi. 
Dinyatakan juga ada sejenis penyakit yang menyerang thalus rumput laut sehingga thalus menjadi putih dan membusuk, dan hal ini terjadi ketika pertumbuhan tanaman sangat lambat.

\section{Kualitas Air}

Dari hasil pengukuran kualitas air di lokasi penelitian diperoleh data kisaran parameter kualitas air, sebagaimana ditunjukkan dalam Tabel 3 berikut.

Tabel 3 : Data kisaran parameter kualitas air selama penelitian

\begin{tabular}{|l|c|c|c|}
\hline \multirow{2}{*}{ Nama Parameter } & \multicolumn{3}{|c|}{ W a k t u } \\
\cline { 2 - 4 } & 06.00 & 13.00 & 17.00 \\
\hline Suhu $\left({ }^{\circ} \mathrm{C}\right)$ & $28,0-29,5$ & $30-33$ & $28,0-31,5$ \\
Salinitas (o/oo) & $31-34$ & $31-33$ & $30,0-32,5$ \\
pH & $7-7,5$ & $7-7,5$ & $7-7,7$ \\
Kecerahan (m) & $5-6,5$ & $9-12$ & $5-6$ \\
Kecepatan arus (cm/detik) & $5,0-6,5$ & $5,0-6,5$ & $5,0-6,5$ \\
\hline
\end{tabular}

Berdasarkan tabel di atas, terlihat bahwa data parameter kualitas air yang diperoleh di lokasi penelitian, baik suhu, salinitas, $\mathrm{pH}$, dan kecerahan, masih memenuhi syarat untuk pertumbuhan rumput laut. Menurut Hidayat $d k k .(1990)$, kejernihan air laut yang baik untuk budidaya rumput laut adalah sampai kedalaman $7-10 \mathrm{~m}$, dan suhu air $23-26^{\circ} \mathrm{C}$ dengan fluktuasinya yang relatif kecil. Sementara menurut Indriani dan Sumiarsih (1999), suhu air yang baik antara $20-28^{\circ} \mathrm{C}$. Perairan lokasi budidaya, sebaiknya memiliki $\mathrm{pH}$ antara $7,3-8,2$, dan kisaran salinitas untuk pertumbuhan rumput laut antara $28-34$ o/oo.

Data parameter kualitas air laut yang tidak memenuhi syarat di lokasi percobaan adalah kecepatan arus. Sesuai pengukuran, parameter ini terukur sebesar $5,0-6,5$ $\mathrm{cm} /$ detik. Sesuai pernyataan Hidayat $d k k$. (1999), pergerakan massa air berupa arus diperlukan rumput laut dalam pertumbuhannya. Arus laut dipahami membawa zat-zat hara yang dibutuhkan rumput laut di samping dapat menghanyutkan kotoran-kotoran yang melekat pada thalus. Meskipun demikian, pergerakan arus dapat juga menghadirkan limbah domestik ke kawasan budidaya yang berasal dari pemukiman penduduk di kawasan pesisir. Untuk itu, kecepatan arus yang baik bagi suatu lokasi pembudidayaan rumput laut adalah $50 \mathrm{~cm} /$ detik. Keadaan di mana perairan lokasi percobaan ini, selama penelitian dilakukan menunjukkan kecepatan arus yang lemah, diperkirakan merupakan penyebab laju pertumbuhan rumput laut relatif sama untuk semua perlakuan variasi jarak tanam.

\section{KESIMPULAN DAN SARAN \\ Kesimpulan :}

Dari hasil penelitian ditemukan bahwa jarak tanam rumput laut ternyata memperlihatkan pertumbuhan rumput laut (Eucheuma cottonii) yang secara mutlak berbeda pada kawasan perairan Desa Uwedikan Kecamatan Luwuk Timur Kabupaten Banggai. Meskipun demikian, berdasarkan hasil analisis ragam dari data percobaan ini, diperoleh kesimpulan sebagai berikut.

1. Perlakuan variasi jarak tanam $(20 \mathrm{~cm}, 30$ $\mathrm{cm}$, dan $40 \mathrm{~cm}$ ) tidak berpengaruh nyata terhadap laju pertumbuhan rumput laut (Eucheuma cottonii) yang dicobakan.

2. Keadaan parameter kualitas air selama penelitian seperti suhu, salinitas, $\mathrm{pH}$ dan kecerahan masih berada pada batas kisaran yang layak untuk mendukung pertumbuhan rumput laut (Eucheuma cottonii) kecuali parameter kecepatan arus. Dalam hal ini, suhu air berkisar antara $28-33^{\circ} \mathrm{C}$, salinitas berkisar antara $30-34 \%$ pH berkisar antara $7-7,5$, kecerahan berkisar antara $5-12 \mathrm{~m}$, dan kecepatan arus sebesar $5-6,5 \mathrm{~cm} /$ detik. 


\section{Saran :}

Penelitian ini masih bersifat membantu untuk memberikan informasi kepada pembudidaya rumput laut. Oleh karena itu perlu dilakukan penelitian lebih lanjut mengenai musim budidaya yang tepat menunjang pertumbuhan rumput laut secara optimal dan perlu diadakan survei lokasi untuk budidaya rumput laut yang cocok baik dari segi kualitas air maupun tempat budidaya.

\section{DAFTAR PUSTAKA}

Afrianto, E dan Liviawaty, 1993. Budidaya Rumput Laut dan Cara Pengolahannya. Penerbit Bhatara. Bandung.

Arief, 1996. Laporan Praktek Kerja Lapang Proses Pembudidayaan Rumput Laut (Gracillaria verrucosa) Pada Tambak Binaan PT. Sumber Tirta Sulawesi Jaya Di Kabupaten Takalar. Fakultas Perikanan. Universitas Muslim Indonesia. Ujung Pandang.

Aslan L.M., 1991. Budidaya Rumput Laut. Kanisius. Yogyakarta.

Atmadja, W.S. dan A. Kadi, 1988. Rumput Laut (Alga) Jenis Budidaya dan Pasca Panen. Proyek Studi Potensi Sumberdaya Alam. LIPI. Jakarta.

Fortes, E.T.G., 1981. Indroduction to Seaweeds Their Characteristic and Economic Importance. Report on Training Course on the Gracilaria Algae. University of Philipines South Cina. Manila. Philipihines.

Gaspersz V., 1995. Teknik Analisis Dalam Penelitian Percobaan. Tarsito. Bandung.

Hidayat A., dkk., 1990. Budidaya Rumput Laut. Usaha Nasional. Surabaya.

Indriani dan Sumiarsih, 1991. Budidaya, Pengelolaan dan Pemasaran Rumput Laut. Penebar Swadaya. Bogor.

Lewa A., 1993. Laporan Praktek Kerja Lapang Usaha Budidaya Rumput Laut (Eucheuma spinosum) Di Desa Nassara Kabupaten Jeneponto Sulawesi Selatan. Universitas Muslim Indonesia. Ujung Pandang.

Romimohtarto dan Sri Juwana, 2001. Biologi Laut. Djambatan. Jakarta.

Winarno F., 1990. Teknologi Pengelolaan Rumput Laut. Pustaka Sinar Harapan. Jakarta. 